\title{
THE EFFECT OF DIFFERENT HARVEST AIDING CHEMICALS ON YIELD AND YIELD COMPONENTS OF COTTON (GOSSYPIUM HIRSUTUM L.)
}

\author{
BEYYAVAŞ, V. \\ Suruc Vocational College, The University of Harran, Sanliurfa-Turkey \\ (e-mail: vbeyyavas@harran.edu.tr; phone: +90530 333 6478) \\ (Received $6^{\text {th }}$ Dec 2018; accepted $4^{\text {th }}$ Feb 2019)
}

\begin{abstract}
This study was conducted to determine the effect of different harvest aid chemicals on the yield and yield components of cotton in the experimental area of Osmanbey Campus in Harran University. The method employed in the study was the randomized complete block design with three replications in growing seasons in 2012 and 2013. The Stoneville-453 cotton cultivar was the subject of the study. Commercial names and compounds of the chemicals used in the experiment were as follows: Sonround (480 g/l Glyphosate), Efhun (Ethephon) (480 g/l Ethephon), Drop Ultra (120 g Thidiazuron $+60 \mathrm{~g}$ Diuron), Finish (480 g Etephon $+60 \mathrm{~g}$ Cyclanalide), and Appeal (54 g Fluthiacet-Methyl). Including the control plots, 10 treatments were performed when the bolls were $60 \%$ open. It was concluded that while the highest seed cotton yield was obtained from the Drop Ultra $600 \mathrm{cc} \mathrm{ha}^{-1}(5422.7 \mathrm{~kg}$ ) and Appeal $75 \mathrm{ml} \mathrm{ha}^{-1}+$ Efhun $3000 \mathrm{ml} \mathrm{ha}^{-1}(5382.3 \mathrm{~kg}$ ) applications in 2012, it was Sonround $3000 \mathrm{ml} \mathrm{ha}$ $(4150.7 \mathrm{~kg})$ that produced the highest yield in 2013. On the other hand, the highest earliness ratio was obtained from the Drop Ultra $300 \mathrm{cc} \mathrm{ha}^{-1}+$ Efhun $3000 \mathrm{ml} \mathrm{ha}^{-1}$ treatment $(96.30 \%$ and $96.30 \%)$ in both years. In the second year of the experiment, seed cotton yield and the number of bolls were lower when compared to the first year. The combination and single mixture treatments had different effects on examined properties.
\end{abstract}

Keywords: Gossypium hirsutum L., defoliant, earliness ratio, boll weight, open boll percentage

\section{Introduction}

Since cotton has a perennial and indeterminate growth property, it continues its vegetative growth as long as the conditions are appropriate. Thus, maturation is delayed (Stewart et al., 2000; Bondada and Oosterhuis, 2001). It is therefore important to harvest quality cotton on time. If a clean seed cotton harvest and higher harvest efficiency are desired, cotton must be defoliated before harvest either by hand or machine. Defoliation can shorten boll opening time by as much as 1-3 days, and provide an earliness ratio ranging between $1 \%$ and $20 \%$ in the first-hand seed cotton harvest (Oğlakçı and Gençer, 1992; Du et al., 2013).

Defoliation can be defined as the process of removing leaves when they become physiologically matured. Defoliation occurs when a release layer is formed at the point where the leafstalk (petiole) is attached to the plant stem (Görmüş, 2014). In order for the separation to come up in the leaves, certain conditions such as water stress (excess water or dehydration) need to be eliminated (Silvertooth, 2001). Separation of leaves, square, and bolls starts only when stress conditions are eliminated. However, separation can also take place within 24 hours after irrigation is applied to the dehydrated plants. In this case, defoliation takes place within 4-6 days (Osborne, 1974). For this reason, defoliation should not be delayed more than 4-5 weeks after the last irrigation.

Defoliants increase the synthesis of ethylene in the cotton plant. By creating an extra layer and encouraging the formation of a release layer at the point where the leafstalk joins the branch or main stem, they cause the leaf to break off. Meanwhile, the increase 
of ethylene in plant tissues causes the rise of the auxin hormone, which promotes the opening of bolls (Morgan et al., 1977; Cathey, 1985; Suttle, 1988).

In addition to assisting the harvest, defoliation provides unspotted fiber, which results in better grades, faster and more efficient picking, faster drying of the dew, and thus early picks. It also helps delay the seed coat decay and encourage the boll opening (Edmisten, 1998). Therefore, it is necessary to use defoliants in order to accelerate the opening of the bolls before harvest, to increase harvesting efficiency, to reduce the seed cotton moisture, fiber contamination, and negative effects of pest and diseases populations (Oğlakçı, 1992). A plant, to which a defoliant or harvest-aid chemicals were applied, might have immature bolls on its top. As a general rule, the maturation of the first boll, placed at the $4^{\text {th }}$ or $5^{\text {th }}$ node downwards from the top boll on the plant to be collected, was used as a main determinant for the defoliant application time (Oğlakçı and Kaynak, 1992; Larson et al., 2005; Çopur et al., 2010). In defoliant applications, obtaining an optimum usage experience and desired result depends on when the farmers apply these defoliants rather than which chemicals they use (Edmisten, 1998). For this reason, the most suitable time of defoliation should be determined by considering genotype properties and region conditions (Çopur et al., 2010).

As a result of early defoliation, the yield is reduced and the fiber quality is negatively affected (Snipes and Baskın, 1994). Similarly, in the case of late defoliation, adverse weather conditions can be a problem (Kerby et al., 1992), and due to low temperature conditions, defoliation cannot be achieved sufficiently. However, late defoliations enable the development of immature bolls, thereby increases the yield. Defoliant timing has also a significant influence on the fiber quality. Too early or too late defoliation affects the fiber quality adversely (Samani et al., 1999; Wright et al., 2014). Early defoliation can be critical for maximum yield. On the other hand, the risk of yield loss as a result of the rain and early frost damages in winter season might be increased when defoliation is delayed (Bange and Milory, 2001).

Many researchers used defoliants and boll-opening chemicals that assist harvesting in their studies (Snipes and Baskın, 1994; Çopur et al., 2010; Du et al., 2013; Singh et al., 2015; Tashaev et al., 2016). Ethephon is a boll opener that is widely used as a chemical aid during the harvest. It increases the yield by increasing the number of opened bolls (Gwathmay and Hayes, 1997; Du et al., 2013; Singh et al., 2015).

While some researchers used a single chemical, others employed a mixture to achieve better results in harvest. If one or more defoliants and boll openers are mixed in the combinations, the activity and response of the defoliant increase positively (Snipes and Cathey, 1992; Gwathmay and Hayes, 1997; Du et al., 2013).

The joint use of defoliant and Etephon increases the rate of first-hand seed cotton yield significantly. But it does not have any effects on the boll weight, ginning outturn, and fiber properties ( $\mathrm{Du}$ et al., 2013). Moreover, defoliant mixture and Ethephon (Thidiazuron+Ethephon and Thidiazuron-Diuron+Ethephon) can increase the number of opened bolls and enhance defoliation efficiency. They also increase the first-hand seed cotton yield more than a single defoliant and boll opener usage (Du et al., 2013).

Many studies have been carried out on defoliants and boll openers. In their study with different defoliants (Dropp Ultra and Round Up) and different application times (60, 75, and 90 days after flowering), Çopur et al. (2010) found out that Dropp Ultra treatment, applied 60 days after flowering, decreased the seed cotton yield, the number of bolls, boll weight and fiber index. However, they also pointed out that the delayed defoliant application increased the number of bolls, seed cotton yield and boll weight, 
and that neither of the treatments had any effects on ginning outturn or fiber quality. On the other hand, Awan et al. (2012) reported that the defoliant treatments resulted in a twenty-five-day earlier harvest and provided a better seed cotton yield when compared to the control plots. In addition, they also argued that the treatments had significantly affected fiber fineness and uniformity, but had no significant effects on fiber strength. In a similar study, Singh et al. (2015) suggested that, after using the defoliants Dropp Ultra and Ethrel (Ethephon), the lowest yield was obtained from the highest dose (Dropp Ultra $225 \mathrm{ml} \mathrm{ha}^{-1}$ ) while the highest yield was from the Dropp Ultra $200 \mathrm{ml} \mathrm{ha}^{-1}$ dose. Moreover, they claimed that the defoliants, applied 150 days after sowing, resulted in a more seed cotton yield when compared to the defoliants applied 140 days after sowing. They also stated that Dropp Ultra defoliant contributed better to the boll opening.

The Harran plain, where the study was conducted, is one of the most important cotton production centers in Turkey. The size of cotton sowing areas and the volume fibre production have increased significantly because of the increase in the number of irrigated lands following the GAP (Southeastern Anatolia Project).

However, in some years, the harvest is significantly delayed due to early autumn rainfalls. Seed cotton harvesting in this region is mostly performed with combine. Therefore, defoliation and boll opening are of great importance for increasing the combine harvest efficiency and a cleaner cotton harvest.

This study was carried out to determine the most appropriate dose or doses of different harvest-aid chemicals (single or mixture) and their effects on the yield and yield components of cotton.

\section{Material and methods}

The study was conducted in the experimental area of Osmanbey Campus in Harran University in accordance with randomized complete block design with three replications in 2012 and 2013 growing seasons. The experimental field is located in Harran Plain

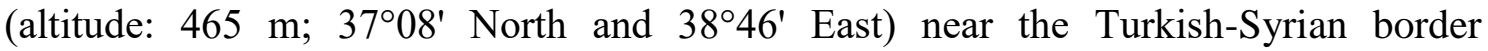
(Figure 1).

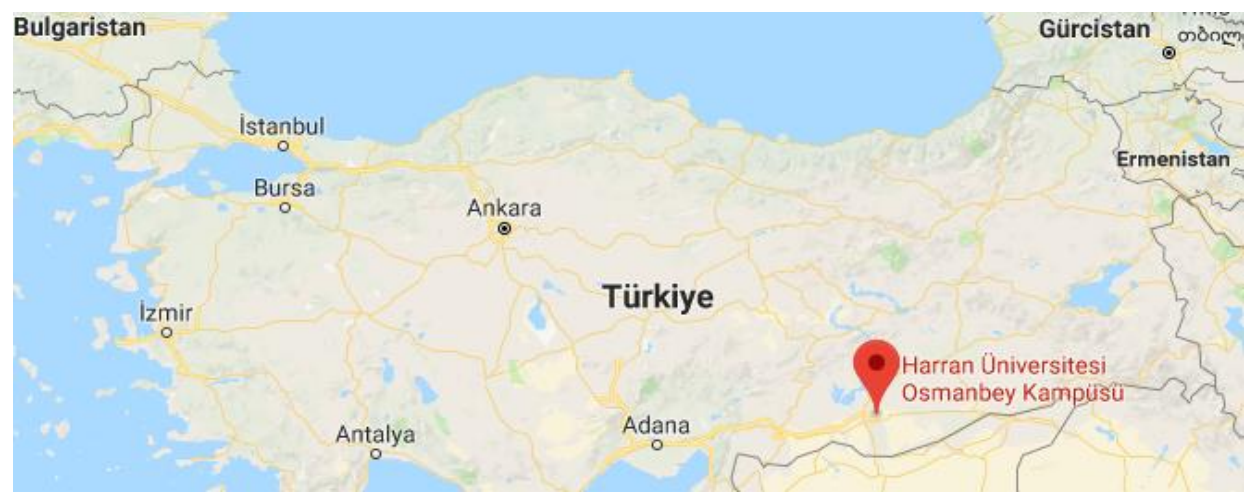

Figure 1. The experimental field

Stoneville-453 cotton cultivar was used as the study subject. ST-453 cotton cultivar Stonoville pedigreed seed co. was developed and registered in 1988 (Calhoun et al., 1997). In our region it was certificated in 1995 and has been widely used since then. 
Especially earliness at an intermediate level, high yield and $42 \%$ gin outturn were the main reasons for farmers' preferring this cotton cultivar (Harem, 2010).

In the experiment, each plot was established with a length of $12 \mathrm{~m}, 6$ rows, $70 \mathrm{~cm}$ inter-rows and $15 \mathrm{~cm}$ intra-rows spaces (Figure 2). Sowing was done on $14^{\text {th }}$ April in 2012, and on $22^{\text {th }}$ April in 2013 with a pneumatic sowing machine. During the experiment, half of the pure nitrogen $(\mathrm{N})$ and all of the pure phosphorus $(\mathrm{P})$ were applied. The $\mathrm{N}$ and $\mathrm{P}$ were applied as $70 \mathrm{~kg} \mathrm{ha}^{-1} \mathrm{~N}$ and $70 \mathrm{~kg} \mathrm{ha}^{-1} \mathrm{P}_{2} \mathrm{O}_{5}$ respectively from a 20.20.0 composed fertilizer at the sowing time. The remaining pure nitrogen was given with the lister tool as $90 \mathrm{~kg} \mathrm{ha}^{-1}$ just before the first irrigation.

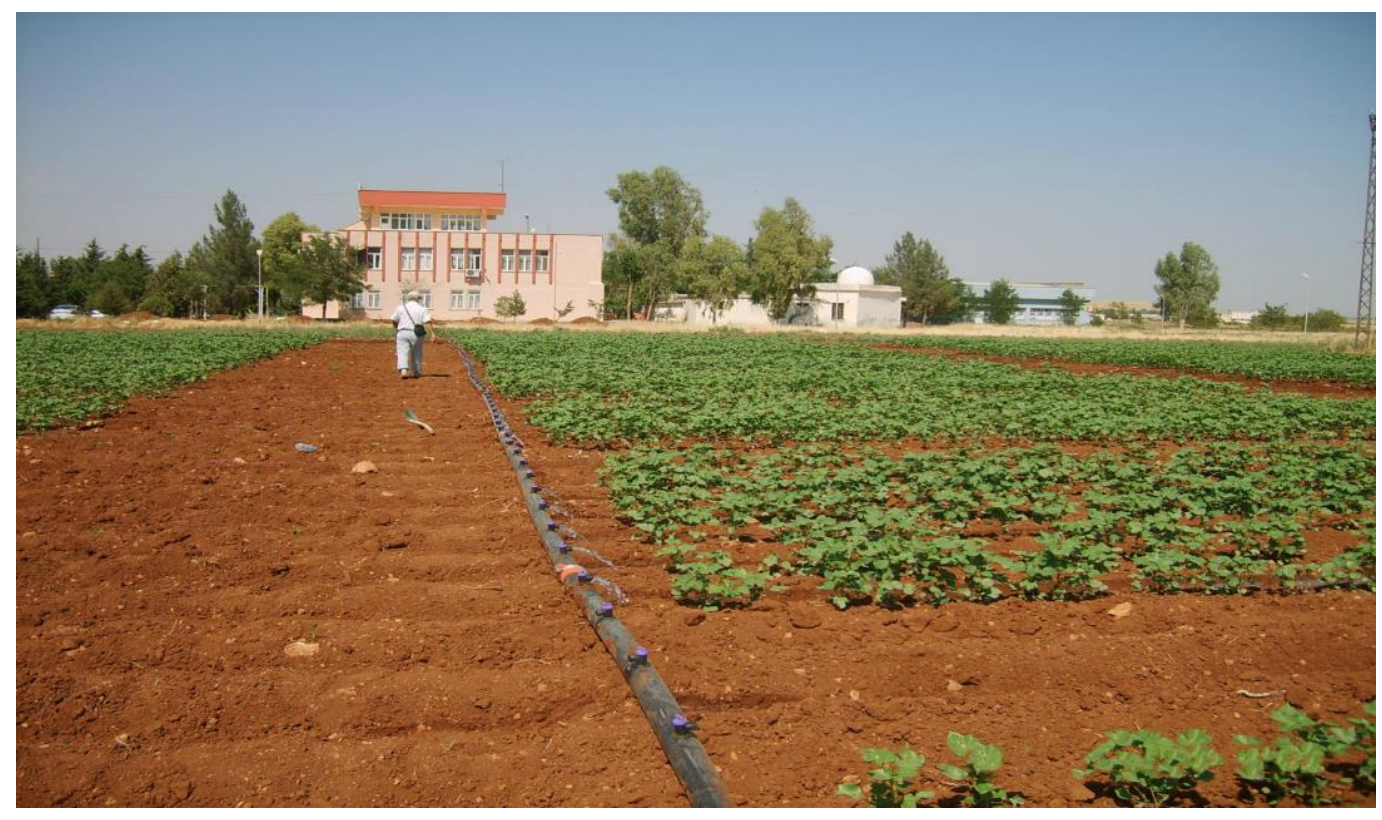

Figure 2. A photography from the experimental field

Total irrigation amount during growing seasons (surface irrigation) was about $1100 \mathrm{~mm}$. The first irrigation was applied 3 weeks after sowing and the second one was 3 weeks after that. Thereafter, the plots were irrigated every 2 weeks until the end of the season, thus providing a total of ten irrigations.

The experimental area was a flat and nearly flat land, and its calcium content was $32 \%$. All soil profiles had high clay content $(60 \%)$ and $\mathrm{pH}$ was from 7.3 to 7.4 . The organic and salinity level was $0.8 \%$ and $0.08 \%$, respectively. It had a high cation exchange capacity of $57.1 \mathrm{meq} / 100 \mathrm{~g}$. Na content in the $0-150 \mathrm{~cm}$ profile was 1.4 . The soil belonged to Ikizce soil series and is classified as vertic calciorthid aridisol (Dinç et al., 1988).

The average temperature during the cotton growth period (from April to October in 2012 and 2013) ranged between $19.3-18.4^{\circ} \mathrm{C}$ in April, $22.4-22.9^{\circ} \mathrm{C}$ in May, 30.6-29 ${ }^{\circ} \mathrm{C}$ in June, 33.3-32 ${ }^{\circ} \mathrm{C}$ in July, 32.3-31. $6^{\circ} \mathrm{C}$ in August, 28.4-26.6 ${ }^{\circ} \mathrm{C}$ in September, and 21.0$19.3^{\circ} \mathrm{C}$ in October (Table 1). The total precipitation was between 0.2 and $42.3 \mathrm{~mm}$ with a monthly average of $18.17 \mathrm{~mm}$ in 2012 (April-October), and between 0 and $56.2 \mathrm{~mm}$ with a monthly average of $12.17 \mathrm{~mm}$ in 2013. In addition, during the experiment period in summer, there was no rain in June, July, August, September, and October in 2013 (Anonymous, 2013). 
Table 1. The official record of Meteorology Directory, Sanliurfa, Turkey

\begin{tabular}{c|c|c|c|c|c|c|c}
\hline \multirow{2}{*}{ Months } & \multicolumn{3}{|c|}{$\mathbf{2 0 1 2}$} & \multicolumn{2}{c|}{$\mathbf{2 0 1 3}$} & $\mathbf{1 9 2 9 - 2 0 1 3}$ \\
\cline { 2 - 7 } & $\begin{array}{c}\text { Monthly } \\
\text { Average } \\
\text { Temp. }{ }^{\circ} \mathbf{C}\end{array}$ & $\begin{array}{c}\text { Precipitation } \\
\text { mm }\end{array}$ & $\begin{array}{c}\text { Average } \\
\text { Relative } \\
\text { Humidity \% }\end{array}$ & $\begin{array}{c}\text { Monthly } \\
\text { Average } \\
\text { Temp. }{ }^{\circ} \mathbf{C}\end{array}$ & $\begin{array}{c}\text { Precipitation } \\
\text { mm }\end{array}$ & $\begin{array}{c}\text { Average } \\
\text { Relative } \\
\text { Humidity \% }\end{array}$ & $\begin{array}{c}\text { Annual } \\
\text { Average Temp. } \\
{ }^{\circ} \mathbf{C}\end{array}$ \\
\hline April & 19.3 & 23.3 & 42.4 & 18.4 & 18.0 & 44.9 & 16.2 \\
May & 22.4 & 42.3 & 40.8 & 22.9 & 56.2 & 43.4 & 22.1 \\
June & 30.6 & 5.8 & 21.2 & 29.0 & - & 24.0 & 28.0 \\
July & 33.3 & 0.2 & 18.8 & 32.0 & - & 20.5 & 31.9 \\
August & 32.3 & 0.2 & 29.0 & 31.6 & - & 22.4 & 31.5 \\
September & 28.4 & 2.0 & 28.0 & 26.6 & - & 33.3 & 27.1 \\
October & 21.0 & 12.5 & 48.5 & 19.3 & - & - & 20.5 \\
November & 14.9 & 31.0 & 65.6 & 14.8 & 19.5 & 57.5 & 13.1 \\
\hline
\end{tabular}

(Anonymous, 2013)

\section{The compounds of the chemicals applied in the experiment are as follows:}

1) Sonround (480 g/L Glyphosate),

2) Efhun (Ethephon) (480 g/L Ethephon),

3) Drop Ultra (120 g/L Thidiazuron $+60 \mathrm{~g} / \mathrm{L}$ Diuron),

4) Finish (480 g/L Etephon $+60 \mathrm{~g} / \mathrm{L}$ Cyclanalide),

5) Appeal (54 g/L Fluthiacet-Methyl).

In both years, chemicals were applied as defoliants in accordance with the recommendations by manufacturers. Both chemicals were mixed with water $\left(300 \mathrm{~L} \mathrm{ha}^{-1}\right)$ and applied by using a backpack sprayer with a pressure set to $4.22 \mathrm{~kg} \mathrm{~cm}^{-2}$. The sprayers were calibrated for a $4.80 \mathrm{~km} \mathrm{~h}^{-1}$ walking speed before each treatment.

\section{Ten defoliant treatments were tested as follows:}

$\mathrm{T}_{1} \quad$ : Sonround (3000 $\left.\mathrm{ml} \mathrm{ha}^{-1}\right)$

$\mathrm{T}_{2} \quad$ : Efhun (3000 $\left.\mathrm{ml} \mathrm{ha}^{-1}\right)$

$\mathrm{T}_{3} \quad$ : Drop Ultra $\left(600 \mathrm{cc} \mathrm{ha}^{-1}\right)$

$\mathrm{T}_{4} \quad$ : Drop Ultra $\left(300 \mathrm{cc} \mathrm{ha}^{-1}\right)+$ Finish $\left(2500 \mathrm{cc} \mathrm{ha}^{-1}\right)$

$\mathrm{T}_{5} \quad$ : Drop Ultra $\left(300 \mathrm{cc} \mathrm{ha}^{-1}\right)+$ Efhun $\left(3000 \mathrm{ml} \mathrm{ha}^{-1}\right)$

$\mathrm{T}_{6} \quad$ : Appeal $\left(1500 \mathrm{ml} \mathrm{ha}^{-1}\right)$

$\mathrm{T}_{7} \quad$ : Appeal $\left(750 \mathrm{ml} \mathrm{ha}^{-1}\right)+$ Efhun $\left(3000 \mathrm{ml} \mathrm{ha}^{-1}\right)$

$\mathrm{T}_{8} \quad$ : Appeal $\left(750 \mathrm{ml} \mathrm{ha}^{-1}\right)+$ Finish $\left(2500 \mathrm{cc} \mathrm{ha}^{-1}\right)$

$\mathrm{T}_{9} \quad$ : Finish $\left(2500 \mathrm{cc} \mathrm{ha}^{-1}\right)$

$\mathrm{T}_{10} \quad$ : Water spray (control plot)

Harvest aiding chemical treatments were applied on September 13 in 2012, and on September 10 in 2013 (when the bolls were opened at 60\% ratio) (Silvertooth, 2001; Edmisten, 2006; Mrunalini et al., 2018). Harvest was made 15 days after the treatments in an area that includes middle two rows of each plot $\left(10 \mathrm{~m} \mathrm{x} 1.4 \mathrm{~m}=14 \mathrm{~m}^{2}\right)$, excluding the 1-meter length from both sides of the plots. The first-hand harvest was done on September 28 and the second-hand harvest on October 27 in 2012, whereas the firsthand harvest was done on September 24 and the second-hand harvest on October 27 in 2013. Twenty plants were randomly chosen from the central row of each plot to 
determine plant height, the number of opened bolls per plant, boll weight ( $\mathrm{g}$ seed cotton boll $\left.^{-1}\right)$, seed cotton yield $\left(\mathrm{g} \mathrm{plant}^{-1}\right)$, and plant height $(\mathrm{cm})$. Earliness as percentage of the yield harvested in the first picking was calculated as follows: seed cotton yield in first picking was divided by the total seed cotton yield and multiplied by 100 . Total seed cotton yield of each plot (including the twenty plant sub samples) was ginned on a laboratory roller gin stand to determine lint yield $\left(\mathrm{kg} \mathrm{lint} \mathrm{he}^{-1}\right)$, lint percent, seed index (g per 100 seeds), and lint index (g of lint per 100 seeds) (Sawan, 2016). Statistical analysis was performed by using the JMP 11 statistical program (SAS Inc.). Means were separated by Fisher's protected least significant differences (LSD) test and $p \leq 0.05$ was denoted as the significance level.

\section{Results and Discussion}

\section{Seed Cotton Yield $\left(\mathrm{kg} \mathrm{ha}^{-1}\right)$}

Different results were obtained from different defoliant treatments in 2012 and 2013 years. The highest seed cotton yields (5422.7 and $\left.5382.3 \mathrm{~kg} \mathrm{ha}^{-1}\right)$ were obtained from the applications of $\mathrm{T}_{3}$ (Drop Ultra $600 \mathrm{cc} \mathrm{ha}^{-1}$ ) and $\mathrm{T}_{7}$ (Appeal $75 \mathrm{ml} \mathrm{ha}^{-1}+$ Efhun $3000 \mathrm{ml} \mathrm{ha}^{-1}$ ) in 2012, and $\mathrm{T}_{1}$ (Sonround $3000 \mathrm{ml} \mathrm{ha}^{-1}$ ) application provided the highest seed cotton yield (4150.7 $\mathrm{kg} \mathrm{ha}^{-1}$ ) in 2013 (Table 2).

Table 2. Seed cotton yield, earliness ratio, and number of bolls in cotton with different harvest aid chemical treatments, and groups formed according to the LSD test

\begin{tabular}{|c|c|c|c|c|c|c|}
\hline \multirow[t]{2}{*}{ Treatments } & \multicolumn{2}{|c|}{$\begin{array}{l}\text { Seed Cotton Yield } \\
\left(\mathrm{kg} \mathrm{ha}^{-1}\right)\end{array}$} & \multicolumn{2}{|c|}{$\begin{array}{c}\text { Earliness Ratio } \\
(\%)\end{array}$} & \multicolumn{2}{|c|}{$\begin{array}{c}\text { Number of Open Bolls } \\
\left(\text { no. } \text { plant }^{-1}\right)\end{array}$} \\
\hline & 2012 & 2013 & 2012 & 2013 & 2012 & 2013 \\
\hline $\mathrm{T}_{1}$ & $4844.3 \mathrm{c}$ & $4150.7 \mathrm{a}$ & $92.23 \mathrm{e}$ & $92.23 \mathrm{~d}$ & $20.07 \mathrm{a}$ & $11.50 \mathrm{~cd}$ \\
\hline $\mathrm{T}_{2}$ & $5042.7 \mathrm{~b}$ & $3700.3 \mathrm{bc}$ & $93.90 \mathrm{~d}$ & $93.90 \mathrm{c}$ & $20.20 \mathrm{a}$ & $12.73 \mathrm{~b}$ \\
\hline $\mathrm{T}_{3}$ & 5429.7 a & $3765.3 \mathrm{ab}$ & $94.53 \mathrm{~cd}$ & $94.47 \mathrm{c}$ & $18.00 \mathrm{c}$ & $10.63 \mathrm{e}$ \\
\hline $\mathrm{T}_{4}$ & $5063.3 \mathrm{~b}$ & $3313.0 \mathrm{c}$ & $92.57 \mathrm{e}$ & $92.23 \mathrm{~d}$ & $16.87 \mathrm{~d}$ & $12.43 \mathrm{~b}$ \\
\hline $\mathrm{T}_{5}$ & $5016.7 \mathrm{~b}$ & $3543.3 \mathrm{bc}$ & $96.30 \mathrm{a}$ & $96.30 \mathrm{a}$ & $17.90 \mathrm{c}$ & $11.33 \mathrm{de}$ \\
\hline $\mathrm{T}_{6}$ & $4576.0 \mathrm{~d}$ & $3552.3 \mathrm{bc}$ & $94.30 \mathrm{~cd}$ & $94.33 \mathrm{c}$ & $20.30 \mathrm{a}$ & $11.43 \mathrm{~d}$ \\
\hline $\mathrm{T}_{7}$ & $5382.3 \mathrm{a}$ & $3898.7 \mathrm{ab}$ & $95.23 \mathrm{~b}$ & $95.23 \mathrm{~b}$ & $19.20 \mathrm{~b}$ & $11.53 \mathrm{~cd}$ \\
\hline $\mathrm{T}_{8}$ & $4933.3 \mathrm{bc}$ & $3751.7 \mathrm{ab}$ & $94.37 \mathrm{~cd}$ & $94.37 \mathrm{c}$ & $17.90 \mathrm{c}$ & $12.23 \mathrm{bc}$ \\
\hline $\mathrm{T}_{9}$ & $4805.7 \mathrm{c}$ & $3326.7 \mathrm{c}$ & $90.80 \mathrm{f}$ & $90.80 \mathrm{e}$ & $18.00 \mathrm{c}$ & $13.73 \mathrm{a}$ \\
\hline $\mathrm{T}_{10}$ (control) & $5014.3 \mathrm{~b}$ & $3676.0 \mathrm{bc}$ & $94.57 \mathrm{c}$ & $94.53 \mathrm{c}$ & $17.07 \mathrm{~d}$ & $13.97 \mathrm{a}$ \\
\hline $\operatorname{LSD}(0.05)$ & 16.74 & 41.22 & 0.64 & 0.66 & 0.62 & 0.75 \\
\hline$\% \mathrm{CV}$ & 1.95 & 6.55 & 0.61 & 0.41 & 1.94 & 3.61 \\
\hline
\end{tabular}

${ }^{*}$ Means in each column followed by the same letter are not significantly different $(\mathrm{p}<0.05)$

If one or more defoliants and boll openers are mixed in the combinations, the activity and response of the defoliant increase positively (Snipes and Cathey, 1992; Gwathmay and Hayes, 1997; Awan et al., 2012; Du et al., 2013). This idea is partially confirmed with an increase in treatments when compared to control plots. Thidiazuron accelerates boll dehiscence by increasing ethylene level in cotton leaves (Suttle, 1985). Light penetration is also improved by leaf removal. These crop conditions lead to early maturity and opening of bolls (Malik et al., 1991). Kerby (1988) stated that with stimulation of defoliation process, leaves transport most of their nutrients and metabolites to developing bolls. Results from this study also indicate that defoliants did not cause yield loss or deterioration in fibre quality in a physiologically matured crop. 
In the second year of the experiment, it was observed that there was a decrease in the seed cotton yield in all treatments, which can be associated with the environment and climate conditions. When the climate data of the year 2013 are examined, it is seen that during the growing period (April-October) the weather (Table 1) was very dry, evaporation was intensive, and precipitation was too low (Anonymous, 2013).

\section{Earliness Ratio (\%)}

In both years of the trial, statistically significant differences have been seen among all treatments in terms of earliness ratio. Of all treatments, the best earliness ratio results were obtained from the $\mathrm{T}_{5}$ subject (Drop Ultra $300 \mathrm{cc} \mathrm{ha}^{-1}+$ Efhun $\left.3000 \mathrm{ml} \mathrm{ha}^{-1}\right)(96.30$ and $96.30 \%$, respectively) (Table 2) in both years. Our findings were compatible with the results of Du et al. (2013) who obtained the highest seed cotton yields in earliness ratio from the defoliant and boll opener Thidiazuron+Ethephon and ThidiazuronDiuron+Ethephon treatments (83 and 87\%). Meanwhile, the lowest earliness ratio was obtained from the $\mathrm{T}_{1}$ (Sonround $3000 \mathrm{ml} \mathrm{ha}^{-1}$ ) and $\mathrm{T}_{4}$ (Drop Ultra $300 \mathrm{cc} \mathrm{ha}^{-1}+$ Finish $2500 \mathrm{cc} \mathrm{ha}^{-1}$ ) in 2012, and $\mathrm{T}_{9}$ (Finish $2500 \mathrm{cc} \mathrm{ha}^{-1}$ ) in 2013 (Table 2).

\section{Number of Bolls (no. plant ${ }^{-1}$ )}

Different groups were formed among all treatments in terms of the number of bolls in both years. As in seed cotton yield, more boll numbers were obtained in 2012 than in 2013. When the climate data of 2013 is analyzed, it is seen that during the growing period (April-October) the weather was very dry and evaporation was very intensive (Anonymous, 2013).

Whereas, in 2012, $\mathrm{T}_{1}$ (Sonround $3000 \mathrm{ml} \mathrm{ha}^{-1}$ ), $\mathrm{T}_{2}$ (Efhun $300 \mathrm{ml} \mathrm{ha}^{-1}$ ), and $\mathrm{T}_{6}$ (Appeal $150 \mathrm{ml} \mathrm{ha}^{-1}$ ) produced the highest number of bolls, in 2013, T9 (Finish $2500 \mathrm{cc}$ $\mathrm{ha}^{-1}$ ) and $\mathrm{T}_{10}$ (Control) gave the highest number of bolls (Table 2). Similarly, while Çopur et al. (2010) reported that the highest number of bolls were obtained from the both late defoliant application and no defoliant application plots, Görmüş et al. (2017) suggested that the highest number of bolls were obtained from the control plots in the second year. These results are also compatible with our findings. The reason for this situation is that the leaves of the plants in the control plots continue to exist with their vitality and they keep producing photosynthesis on the plant.

\section{Number of Open Bolls (no. plant ${ }^{-1}$ )}

In both years, statistically different groups were formed in terms of the number of open bolls. In the first year of the experiment, the highest number of open bolls (18.60 per plant) was taken from the $\mathrm{T}_{2}$ subject (Efhun $3000 \mathrm{ml} \mathrm{ha}^{-1}$ ) (Table 3). However, in the second year of the experiment, $\mathrm{T}_{10}$ (Control) formed the highest number of open bolls (12.40 per plant) in all treatments. When the climate data were taken into consideration (Anonymous, 2013), it can be said that since the summer was dry, the plants in the control plots were bent to open more bolls and to be matured.

\section{Number of Unopened Bolls (no. plant ${ }^{-1}$ )}

As shown in Table 3, statistically different groups were formed in terms of the number of unopened bolls in both years. $\mathrm{T}_{10}$ (Control) formed a greater number of unopened bolls (1.83 no. plant ${ }^{-1}$ ) than other treatments in 2012. On the other hand, $T_{5}$ (Drop Ultra $300 \mathrm{cc} \mathrm{ha}^{-1}+$ Efhun $3000 \mathrm{ml} \mathrm{ha}^{-1}$ ) mixture yielded the best result 
(0.83 no. plant $\left.{ }^{-1}\right)$. The result of Singh et al. (2015) illustrates that Dropp Ultra defoliant promotes the boll opening better. This is consistent with our study. For, T9 Finish (2500 $\left.\mathrm{cc} \mathrm{ha}^{-1}\right)$ gave the highest number of unopened bolls $\left(1.83\right.$ no. plant $\left.{ }^{-1}\right)$ in 2013 . The best results $\left(0.80\right.$ no. plant ${ }^{-1}$ ) was taken from the $\mathrm{T}_{1}$ (Sonround $3000 \mathrm{ml} \mathrm{ha}^{-1}$ ) application.

Table 3. Number of open bolls, number of unopened bolls, and boll weight in cotton with different harvest aid chemical treatments, and groups formed according to the LSD test

\begin{tabular}{c|c|c|c|c|c|c}
\hline \multirow{2}{*}{ Treatments } & \multicolumn{2}{|c|}{$\begin{array}{c}\text { Number of Open Bolls } \\
\text { (no. plant } \mathbf{H}^{-1} \text { ) }\end{array}$} & $\begin{array}{c}\text { Number of Unopened Bolls } \\
\text { (no. plant }^{-1} \text { ) }\end{array}$ & \multicolumn{2}{|c}{$\begin{array}{c}\text { Boll Weight } \\
\text { (g) }\end{array}$} \\
\cline { 2 - 7 } & $\mathbf{2 0 1 2}$ & $\mathbf{2 0 1 3}$ & $\mathbf{2 0 1 2}$ & $\mathbf{2 0 1 3}$ & $\mathbf{2 0 1 2}$ & $\mathbf{2 0 1 3}$ \\
\hline $\mathrm{T}_{1}$ & $18.47 \mathrm{ab}$ & $10.70 \mathrm{~cd}$ & $1.53 \mathrm{~b}$ & $0.80 \mathrm{e}$ & $6.73 \mathrm{a}$ & $5.97 \mathrm{e}$ \\
$\mathrm{T}_{2}$ & $18.60 \mathrm{a}$ & $11.63 \mathrm{~b}$ & $1.60 \mathrm{~b}$ & $1.07 \mathrm{~d}$ & $6.30 \mathrm{~cd}$ & $6.37 \mathrm{bc}$ \\
$\mathrm{T}_{3}$ & $18.87 \mathrm{~cd}$ & $9.20 \mathrm{e}$ & $1.13 \mathrm{~cd}$ & $1.37 \mathrm{bc}$ & $6.40 \mathrm{bc}$ & $6.20 \mathrm{~cd}$ \\
$\mathrm{~T}_{4}$ & $15.87 \mathrm{e}$ & $10.97 \mathrm{c}$ & $1.00 \mathrm{dc}$ & $1.40 \mathrm{bc}$ & $6.37 \mathrm{bc}$ & $6.67 \mathrm{a}$ \\
$\mathrm{T}_{5}$ & $17.27 \mathrm{c}$ & $10.23 \mathrm{~d}$ & $0.83 \mathrm{e}$ & $1.03 \mathrm{de}$ & $6.57 \mathrm{abc}$ & $5.93 \mathrm{e}$ \\
$\mathrm{T}_{6}$ & $18.33 \mathrm{ab}$ & $10.23 \mathrm{~d}$ & $1.63 \mathrm{ab}$ & $1.23 \mathrm{~cd}$ & $6.57 \mathrm{abc}$ & $6.33 \mathrm{bc}$ \\
$\mathrm{T}_{7}$ & $18.00 \mathrm{~b}$ & $10.27 \mathrm{~d}$ & $1.20 \mathrm{~cd}$ & $1.27 \mathrm{~cd}$ & $6.67 \mathrm{ab}$ & $6.20 \mathrm{~cd}$ \\
$\mathrm{~T}_{8}$ & $16.77 \mathrm{~d}$ & $10.90 \mathrm{c}$ & $1.13 \mathrm{~cd}$ & $1.33 \mathrm{bc}$ & $6.47 \mathrm{abc}$ & $6.23 \mathrm{~cd}$ \\
$\mathrm{~T}_{9}$ & $16.70 \mathrm{~d}$ & $11.90 \mathrm{ab}$ & $1.30 \mathrm{c}$ & $1.83 \mathrm{a}$ & $6.03 \mathrm{~d}$ & $6.50 \mathrm{ab}$ \\
$\mathrm{T}_{10}(\mathrm{control})$ & $15.67 \mathrm{e}$ & $12.40 \mathrm{a}$ & $1.83 \mathrm{a}$ & $1.57 \mathrm{~b}$ & $6.60 \mathrm{abc}$ & $6.10 \mathrm{de}$ \\
$\mathrm{LSD}(0.05)$ & 0.49 & 0.57 & 0.22 & 0.24 & 0.313 & 0.19 \\
$\% \mathrm{CV}$ & 1.64 & 3.07 & 9.65 & 10.49 & 2.82 & 1.50 \\
\hline
\end{tabular}

*Means in each column followed by the same letter are not significantly different $(\mathrm{p}<0.05)$

\section{Boll Weight (g)}

The highest boll weight $(6.73 \mathrm{~g})$ was obtained from the $\mathrm{T}_{1}$ (Sonround $3000 \mathrm{ml} \mathrm{ha}^{-1}$ ) in 2012 and from the $\mathrm{T}_{4}$ (Drop Ultra $300 \mathrm{cc} \mathrm{ha}^{-1}+$ Finish $\left.250 \mathrm{cc} \mathrm{ha}^{-1}\right)(6.67 \mathrm{~g})$ in 2013. Defoliant and boll-opening treatments gave better results when compared to the control plots (Table 3). This situation reveals that defoliant and boll openers increase boll weight. In parallel with our study, Awan et al. (2012) report that the defoliant and sulfur doses gave better results than control plots in terms of boll weight.

\section{Boll Seed Cotton Weight (g)}

Statistically significant different groups were formed among all treatments in terms of the boll seed cotton weight in both years (Table 4). The highest boll seed cotton weight $\left(5.03 \mathrm{~g}\right.$ ) was obtained from the $\mathrm{T}_{1}$ (Sonround $3000 \mathrm{ml} \mathrm{ha}^{-1}$ ) in 2012 from the $\mathrm{T}_{4}$ (Drop Ultra $300 \mathrm{cc} \mathrm{ha}^{-1}+$ Finish $250 \mathrm{cc} \mathrm{ha}^{-1}$ ) (4.20 g) in 2013. Awan et al. (2012) claim that the defoliant and sulfur doses gave better results than control plots in terms of boll seed cotton weight. This is confirmed in our study, as well.

\section{Ginning Outturn (\%)}

In terms of ginning outturn, there were statistically significant differences between the treatments only in 2012. The highest ginning outturn was obtained from the $\mathrm{T}_{8}$ (Appeal $75 \mathrm{ml} \mathrm{ha}^{-1}+$ Finish $2500 \mathrm{cc} \mathrm{ha}^{-1}$ ) (41.97\%) in 2012 (Table 4). These differences between years may be resulting from differences in climate factors. However, in their studies, Denizdurduran and Efe (2009), Çopur et al. (2010), Du et al. (2013), and Tülemen (2016) state that the ginning outturn differences are not significant. 


\section{Seed Index (g)}

Different groups were formed among all treatments in terms of 100 seed weight in both years. In 2012, while the highest seed index weight $(8.73 \mathrm{~g})$ was obtained from the $\mathrm{T}_{7}$ (Appeal $75 \mathrm{ml} \mathrm{ha}^{-1}+$ Efhun $300 \mathrm{ml} \mathrm{ha}^{-1}$ ) and the lowest value was received from the $\mathrm{T}_{10}$ (Control) $(7.83 \mathrm{~g})$ treatment. All treatments formed more seed indexes than control plots (Awan et al., 2012). On the other hand, $\mathrm{T}_{1}, \mathrm{~T}_{2}, \mathrm{~T}_{5}, \mathrm{~T}_{8}, \mathrm{~T}_{9}$ and $\mathrm{T}_{10}$ (control) had the highest seed indexes (Table 4) in 2013. This variability between years can be attributed to changing of climatic conditions (Anonymous, 2013).

Table 4. Boll seed cotton weight, ginning outturn, and seed index in cotton with different harvest aid chemical treatments, and groups formed according to the LSD test

\begin{tabular}{c|c|c|c|c|c|c}
\hline \multirow{2}{*}{ Treatments } & \multicolumn{2}{|c|}{ Boll Seed Cotton Weight (g) } & \multicolumn{2}{c|}{ Ginning Outturn (\%) } & \multicolumn{2}{|c}{ Seed Index (g) } \\
\cline { 2 - 7 } & $\mathbf{2 0 1 2}$ & $\mathbf{2 0 1 3}$ & $\mathbf{2 0 1 0}$ & $\mathbf{2 0 1 3}$ & $\mathbf{2 0 1 2}$ & $\mathbf{2 0 1 3}$ \\
\hline $\mathrm{T}_{1}$ & $5.03 \mathrm{a}$ & $4.70 \mathrm{~d}$ & $40.27 \mathrm{~d}$ & 39.60 & $8.33 \mathrm{~b}$ & $9.67 \mathrm{a}$ \\
$\mathrm{T}_{2}$ & $4.70 \mathrm{~b}$ & $5.00 \mathrm{bc}$ & $40.60 \mathrm{~cd}$ & 39.67 & $8.43 \mathrm{~b}$ & $9.37 \mathrm{a}$ \\
$\mathrm{T}_{3}$ & $4.70 \mathrm{~b}$ & $4.93 \mathrm{c}$ & $40.23 \mathrm{~d}$ & 40.23 & $8.53 \mathrm{ab}$ & $9.03 \mathrm{c}$ \\
$\mathrm{T}_{4}$ & $4.70 \mathrm{~b}$ & $5.20 \mathrm{a}$ & $41.67 \mathrm{ab}$ & 40.07 & $8.37 \mathrm{~b}$ & $9.30 \mathrm{~b}$ \\
$\mathrm{~T}_{5}$ & $4.80 \mathrm{ab}$ & $4.70 \mathrm{~d}$ & $41.53 \mathrm{ab}$ & 41.07 & $8.50 \mathrm{ab}$ & $9.87 \mathrm{a}$ \\
$\mathrm{T}_{6}$ & $4.90 \mathrm{ab}$ & $4.97 \mathrm{bc}$ & $40.53 \mathrm{~cd}$ & 40.43 & $8.57 \mathrm{ab}$ & $9.33 \mathrm{~b}$ \\
$\mathrm{~T}_{7}$ & $4.93 \mathrm{ab}$ & $4.93 \mathrm{c}$ & $41.43 \mathrm{ab}$ & 40.43 & $8.73 \mathrm{a}$ & $8.80 \mathrm{~d}$ \\
$\mathrm{~T}_{8}$ & $4.80 \mathrm{ab}$ & $5.03 \mathrm{bc}$ & $41.97 \mathrm{a}$ & 39.77 & $8.33 \mathrm{~b}$ & $9.73 \mathrm{a}$ \\
$\mathrm{T}_{9}$ & $4.40 \mathrm{c}$ & $5.10 \mathrm{ab}$ & $41.87 \mathrm{ab}$ & 39.93 & $8.47 \mathrm{ab}$ & $9.77 \mathrm{a}$ \\
$\mathrm{T}_{10}(\mathrm{control})$ & $4.83 \mathrm{ab}$ & $4.73 \mathrm{~d}$ & $41.17 \mathrm{bc}$ & 40.67 & $7.93 \mathrm{c}$ & $9.87 \mathrm{a}$ \\
LSD $(0.05)$ & 0.25 & 0.15 & 0.73 & $\mathrm{~ns}$ & 0.89 & 0.22 \\
$\% \mathrm{CV}$ & 3.03 & 1.82 & 1.04 & 1.16 & 1.97 & 1.33 \\
\hline
\end{tabular}

* Means in each column followed by the same letter are not significantly different $(p<0.05)$

\section{Conclusion}

While the $\mathrm{T}_{3}$ (Drop Ultra $\left.600 \mathrm{cc} \mathrm{ha}^{-1}\right)\left(5422.7 \mathrm{~kg}\right.$ ) and $\mathrm{T}_{7}$ (Appeal $750 \mathrm{ml} \mathrm{ha}^{-1}+$ Efhun $3000 \mathrm{ml} \mathrm{ha}^{-1}$ ) subjects gave the highest seed cotton yield $\left(5382.3 \mathrm{~kg} \mathrm{ha}^{-1}\right)$ in 2012, $\mathrm{T}_{1}$ (Sonround $3000 \mathrm{ml} \mathrm{ha}^{-1}$ ) gave the highest seed cotton yield $(4150.7 \mathrm{~kg}$ ) in 2013. In both years, the best results were obtained from the $\mathrm{T}_{5}$ (Drop Ultra $300 \mathrm{cc} \mathrm{ha}^{-1}+$ Efhun $3000 \mathrm{ml} \mathrm{ha}^{-1}$ ) in terms of earliness ratio (96.30 and $96.30 \%$, respectively). Furthermore, the seed cotton yield and the number of bolls were observed to be lower in the second year when compared to the first year. $\mathrm{T}_{1}$ (Sonround $\left.3000 \mathrm{ml} \mathrm{ha}^{-1}\right)(5.03 \mathrm{~g})$ in 2012 and $\mathrm{T}_{4}$ (Drop Ultra $300 \mathrm{cc} \mathrm{ha}^{-1}+$ Finish $250 \mathrm{cc} \mathrm{ha}^{-1}$ ) (4.20 g) in 2013 provided the best results in terms of boll weight. Different groups were formed among all treatments in terms of seed index in both years. In the study, combination and single mixture treatments had shown different effects on the examined properties. In addition, according to the results of the present study, it was found that the increase in combine harvesting has contributed to a clean and timely picking of cotton in recent years. Therefore, it becomes compulsory to use harvest aiding chemicals. In conclusion, although defoliants and boll openers increase the yield slightly, we recommend the farmers to use them since they have no negative impacts on the plants. 


\section{REFERENCES}

[1] Anonymous, (2013): Official record of Meteorology Directory. - Şanlıurfa, Turkey.

[2] Awan, H. U., Awan, I. U., Mansoor, M., Khakvani, A. A., Khan, M. A., Ghazanfarullah, Khattak, B. (2012): Effect of defoliant application at different stages of boll maturity and doses of sulfur on yield and quality of upland cotton. - Sarhad J. Agric. 28(2): 245-247.

[3] Bange, M. P., Milroy, S. P. (2001): Timing of crop maturity in cotton: Impact of dry matter production and partitioning. - Field Crop Res. 2(10):143-145.

[4] Bondada, B. R., Oosterhuis, D. M. (2001): Conopy photosynthesis, specific leaf weight and yield components of cotton under varying nitrogen supply. - Journal of Plant Nitrition 24: 469-477.

[5] Cathey, W. G. (1985): Conditioning Cotton for Increased Response to Defoliant Chemicals. - Field Crops Res. 10: 347-353.

[6] Çopur, O., Demirel, U., Polat, R., Gür, M. A. (2010): Effect of different defoliants and application times on the yield and quality components of cotton in semi-arid conditions. African J. Biotechnol. 9: 2095-2100.

[7] Denizdurduran, N., Efe, L. (2009): The influence of defoliation timing on yield and quality properties of cotton (G. hirsutum L.) under Kahramanmaraş conditions. - The 8th National Field Crops Congress of Turkey, Proroceedings of Industry Plant Vol. 2. 19-22 October, 2009, University of Mustafa Kemal, Faculty of Agriculture, Depertmen of Field Crops, Hatay-Turkey (Turkish).

[8] Dinç, U., Şenol, S., Sayin, M., Kapur, S., Güzel, N., Derici, R., Yeşilsoy, M. S., Yeğingil, I., Sari, M., Kaya, Z., Aydin, M., Kettaş, F., Berkman, A., Çolak, A. K., Yilmaz, K., Tunçgögüs, B., Özbek, H., Gülüt, K. Y., Karaman, C., Öztürk, N., Kara, E. E. (1988): Harran plain soils. - Çukurova University Agricultural Faculty Soil Science Department. TÜBİTAK-TOAG, Project Number:534 (Turkish).

[9] Du, M. W., Ren, X. M., Tian, X. L., Duan, L. S., Zhang, M. C., Tan, W. M., Li, Z. H. (2013): Evaluation of harvest aid chemicals for the cotton-winter wheat double cropping system. - Journal of Integrative Agriculture 12(2): 273-282.

[10] Edmisten, K. L. (1998): The Cotton Plant. - In: Cotton Information. North Carolina Cooperative Extension Service, Pub. AG-417.

[11] Edmisten, K. L. (2006): Cotton Defoliation. - In: Edmiston, K. L. (ed.) North Carolina Cotton Information. Publ. AG-417. Carolina Cooperative Ext. Serv., Raleigh, NC. P.159178.

[12] Görmüş, Ö. (2014): Fiber Plants (Cotton). - Cukurova University, Deparment of Field Crops. First Edition. Adana, Turkey.

[13] Görmüş, Ö., Kurt, F., El Sabagh, A. (2017): Impact of defoliation timings and leaf pubescence on yield and fiber quality of cotton. - J. Agr. Sci.Tech. 19: 903-915.

[14] Gwathmey, C. O., Hayes, R. M. (1997): Harvest-aid interactions under different temperature regimes in field-grown cotton. - Journal of Cotton Science. 1:1-9.

[15] Harem, E. (2010): Türkiye' de Tescil Edilen Pamuk Çeşitleri. - Tarım ve Köyişleri Bakanlığı, Tarımsal Araştırmalar Genel Müdürlüğü Gap Toprak-Su Kaynakları ve Tarımsal Araştırma Enstitüsü Müdürlüğü, Yayın No:165. Şanliurfa, Turkey.

[16] Kerby, T. A. (1988): Cotton physiology and cotton harvest aid. - Cotton Consultant Conference. pp: 1-7. ICI. America Inc.

[17] Kerby, T. A., Supak, J., Banks, J. C., Snipes, C. (1992): Timing defoliant using nodes above cracked boll. - In: Proc. Beltwide Cotton Conf.: 155-156.

[18] Larson, J. A., Gwathmey, C. O., Hayes, R. M. (2005): Effect of defolation timing desiccation on net revenuas from ultra-narrow- row. - J. Cotton Sci. 9: 204-224.

[19] Malik, M. N., Din, S., Makhdum, M. I. (1991): Accelerated boll dehiscence with thidiazuron. - Tropical Agriculture 68: 149-150. 
[20] Morgan, P. W., Jordan, W. R., Davenport, T. L., Durham, J. I. (1977): Abscission responses to moisture stres. auxin transport inhibitors, and ethephon. - Plant Physiology 59: 710-712.

[21] Mrunalini, K., Rekha, M. S., Murthy, V. R. K. (2018): Effectiveness of harvest - aid defoliants and environmental conditions in high density cotton. Int.J.Curr.Microbiol.App.Sci. 7(02): 2312-2316.

[22] Oğlakçı, M. (1992): Defoliation and defoliation physiology in cotton plant. - University of Harran (Şanlıurfa-Turkey). J. Faculty Agric. 3(4): 84-95.

[23] Oğlakç1, M., Gençer, O. (1992): A Research on the damages effect of peak bud damages and leaf cotyledon on cotton's (G. hirsutum L.) yield and quality factors in the first growth stage. - D.Ü. Journal of Faculty of Agriculture. 3(3) s: 1-11.

[24] Oğlakçı, M., Kaynak, M. A. (1992): Harvest-aid chemical aplications in cotton cultivation. - University of Harran (Şanlıurfa-Turkey). J. Faculty Agric. 3(4): 78-83 (Turkish).

[25] Osborne, D. J. (1974): Hormones and the shedding of leaves and bolls. - Cotton Growing Review 51: 256-265.

[26] Samani, M. R. K., Khajehpour, M. R., Ghavaland, A. (1999): Effect of row spacing and plant density on growt and dry matter accumulation in cotton on Isfhan, Iran. - J. Agric. Sci. 29: 667-669.

[27] Sawan, Z. M. (2016): Plant density plant growth reterdans: Its direct and residual effects on cotton yields and fiber properties. - Cogent Biology 2:1234959.

[28] Silvertooth, J. C. (2001): Crop management for defoliation. - http://cals. Arizona. edu /pubs/crops /az1213.pdf.

[29] Singh, K., Rathore, P. (2015): Effect of different defoliants and their rate and time of application on American cotton cultivars under semi-arid conditions of North-Western India. - Research on crops 16(2): 258-263. Prinred on India.

[30] Snipes, C. E., Cathey, G. W. (1992): Evaluation of defoliant mixtures in cotton. - Field Crops Research 28: 327-334.

[31] Snipes, C. E., Baskin, C. C. (1994): Influence of early defoliation on cotton yield, seed quality, and fiber properties. - Field Crops Research 37: 137-143.

[32] Stewart, A. M., Edmisten, K. L., Wells, R. (2000): Boll openers in cotton: effectiveness and environmental influences. - Field Crops Research 67: 83-90.

[33] Suttle, J. C. (1985): Involvement of ethylene in the action of the cotton defoliant thidiazuron. - Plant Physiology 78: 272-276.

[34] Suttle, J. C. (1988): Distruption of the polar auxin transport system in cotton seedlings following treatment with the defoliant thidiazuron. - Plant Physiology 86: 241-245.

[35] Tashaev, F., Raxmatov, I., Allanazarov, C., Abduraxmonov, U., Khaitov, B. (2016): Effeciency of new defoliants in the cotton production. - International Journal of Applied Agricultural Research ISSN 0973-2683 Volume 11, Number 1: 65-69.

[36] Tülemen, A. S. (2016): The effects of defoliants on important morphological, agronomical and technological features on short season cotton (Gossypium hirsutum L.). - Adnan Menderes University Graduate School of Natural and Applied Sciences Department of Field Crops.

[37] Wright, S. D., Hutmacher, R. B., Banuelos, G., Rios, S. I., Hutmacher, K. A., Munk, D. S., Wilson, K. A., Wrobles, J. F., Keeley, M. P. (2014): Impact of pima defolation timings on lient yield and quality. - The Journal of Cotton Science 18: 48-58. 